\title{
Diversity of edible insects in a Natural World Heritage Site of India: entomophagy attitudes and implications for food security in the region
}

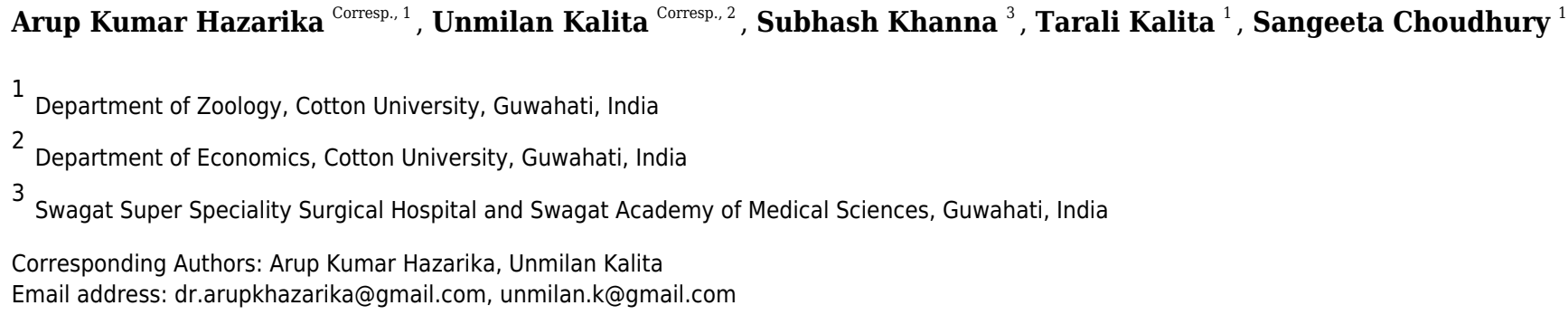

Insects not only play a significant role in the ecological process of nature but since prehistoric times have also formed a part of the human diet. With a still growing population and skewed demographic structures across most societies of the world, their role as nutrient-rich food has been increasingly advocated by researchers and policymakers globally. In this study, we examine the edible insect diversity and entomophagy attitudes of ethnic people in Manas National Park, a UNESCO Natural World Heritage Site, located in Assam (India). The study involved a field investigation through which the pattern of entomophagy and the attitude towards insect-eating was studied. Following this, we examined the edible insect diversity and abundance at different sampling points. A total of 22 species of edible insects belonging to fifteen families and eight orders were recorded from different habitat types. Out of these 22 species, Orthopterans showed a maximum number of 8 species followed by Hymenoptera (4), Hemiptera (3), Lepidoptera (2), Blattodea (2) and 1 species each from Coleoptera, Odonata, and Mantodea. Dominance, diversity, and equitability indices were computed along with the relative abundance of the insects concerning four habitat types. Aspects of the economic significance of entomophagy were also observed during the field investigation. To manage insects in the interest of food security, more attention should be given to sustainable collecting and rearing methods emphasizing their economic, nutritional, and ecological advantages. 
1 Diversity of edible insects in a Natural World Heritage 2 Site of India: entomophagy attitudes and implications 3 for food security in the region

4 Running title: Edible insects and Food Security 5

\title{
Corresponding Authors:
}

\section{Arup Kumar Hazarika}

Department of Zoology, Cotton University, Guwahati, Assam, India

Email address: dr.arupkhazarika@gmail.com

Unmilan Kalita

Department of Economics, Cotton University, Guwahati, India

Email address: unmilan.k@gmail.com

\begin{abstract} Insects not only play a significant role in the ecological process of nature but since pre-historic times have also formed a part of the human diet. With a still growing population and skewed demographic structures across most societies of the world, their role as nutrient-rich food has been increasingly advocated by researchers and policymakers globally. In this study, we examine the edible insect diversity and entomophagy attitudes of ethnic people in Manas National Park, a UNESCO Natural World Heritage Site, located in Assam (India). The study involved a field investigation through which the pattern of entomophagy and the attitude towards insect-eating was studied. Following this, we examined the edible insect diversity and abundance at different sampling points. A total of 22 species of edible insects belonging to fifteen families and eight orders were recorded from different habitat types. Out of these 22 species, Orthopterans showed a maximum number of 8 species followed by Hymenoptera (4), Hemiptera (3), Lepidoptera (2), Blattodea (2) and 1 species each from Coleoptera, Odonata, and Mantodea. Dominance, diversity, and equitability indices were computed along with the relative abundance of the insects concerning four habitat types. Aspects of the economic significance of entomophagy were also observed during the field investigation. To manage insects in the interest of food security, more
\end{abstract}


40 attention should be given to sustainable collecting and rearing methods emphasizing their 41 economic, nutritional, and ecological advantages.

42 


\section{Introduction}

44 Insects are the most diverse and abundant forms of life and constitute a primary component of

45

46

47

48

49

50

51

52

53

54

55

56

57

58

59

60

61

62

63

64

65

66

67

68

69

70

71

72

73

74

75

76

77

78

79

80

81

82 the total faunal biodiversity on Earth. They play vital roles in an ecosystem that includes soil turning and aeration, dung burial, pest control, pollination, and wildlife nutrition (Bernard \& Womeni, 2017). Besides providing ecological services, insects are also an important source of protein, fat, carbohydrate, and other nutrients. As per the current scientific literature, there are 1.4 million species of insects worldwide which are an intrinsic part of the Earth's ecosystem. As such, they arouse interest not only with their immense species richness but also with their species variety and their role in energy flow. A dimension of their existence not to be overlooked pertains to the fact that they have formed a part of human diets since prehistoric times. Evidence points to at least 113 countries where insects form or formed a part of human diets in one way or the other. This practice of consuming insects as part of the human diet is referred to as entomophagy (Evans et al., 2015). Insect-eating or entomophagy is nowadays no longer a traditional or common practice in most countries, except for some in South- and South-East Asia, Latin America, and Africa (Rumpold \& Schluter, 2013), where more than 2,000 insect species are consumed (Jongema, 2015). Given the shortfalls of the 'green revolution' and high risk of food insecurity in developing and underdeveloped nations, the use of insects as a potential source of food for the burgeoning human population had been advocated by Meyer-Rochow (1975), a suggestion that has been gaining interest among researchers, entrepreneurs and policy makers worldwide ever since.

Insect farming is popular in many Asian nations for food, feed, and other purposes (Zhang et al., 2008). Weaver ants (Occophylla smaragdina), whose chemical composition and value as a human food item is well known are widespread in the Asia-Pacific region and are found from China's south to northern Australia and as far west as India. Although edible insects are not yet of much commercial value, some economic and marketing data on edible insects in Asia and the Pacific are available scarce (Johnson, 2010). Approximately 50 insect species are eaten in Thailand's north and about 14 species are eaten by people in southern Thailand (Rattanapan, 2000).The insect-eating habits in various regions depend on the indigenous populations' cultural practices, religion and the place they call home. But insects used as emergency food during natural calamities or other national contingencies as well as for their organoleptic characteristics can also be important (Dumont, 1987).

The North-Eastern part of India has diverse ethnic groups that have a unique culture of food intake with insect-eating mostly prevalent amongst rural tribal people of the region which have a long-cultured history. A total of 81 species are eaten in Arunachal Pradesh by the Galo and Nyishi tribes (Chakravorty et al., 2011). Odonata were consumed the most followed by Orthoptera, Hemiptera, Hymenoptera, and Coleoptera.

Scientific reports indicate insects to be significant sources of not only proteins and vitamins, but also lipids, minerals, fibre and carbohydrates. Insects possess a viability of providing daily

Peerj reviewing PDF | (2020:05:49115:3:2:NEW 3 Oct 2020) 
83 requirements of these nutrients in most developing countries (Bukkens, 1997; Elemo et al.,

84 2011). For instance, edible aquatic beetles play an important role in the nutrition and economy of

85 the rural population in Asian, Latin American and African nations (Macadam \& Stockan, 2017)

86 and are popular in Manipur (Shantibala et al., 2014). It should be noted that the diversity and

87 abundance of insects in different habitat types have an observed correlation with the

88 entomophagy attitude of a particular region. Therefore, research indicates the importance of

89 exploiting insect diversity effectively through insect farming to avoid global problems associated

90 with dependency on a limited number of insect species as experienced with some food animals

91 and crops.

92

93

94

In this research article, we have made an effort to study the edible insect diversity of a UNESCO Natural World Heritage Site, located in the Indo-Burmese biodiversity hotspot. Regional

95

96

97

98

99

100

101

102

103

104

105

106

107

108

109

110

111

112

113

114

115

116

117

118

119

120

121

122

entomophagy was studied through a field investigation. We made an effort to determine the degree to which the ethnic people use insects in their diet and which species they consume.

Recording seasonal abundance and availability of edible species as well as evaluating the role that entomophagy could possibly play as a measure of food security in the region, were further aspects of this study.

\section{Materials \& Methods}

\section{Study Area}

The Manas National Park (MNP), located at $26.6594^{\circ} \mathrm{N}, 91.0011^{\circ} \mathrm{E}$, was declared a UNESCO Natural World Heritage Site (WHS) in 1985 (Figure 1). Renowned for its array of rich, rare, and endangered wildlife not found anywhere else in the world, the faunal diversity of MNP includes the Pygmy Hog, Golden Langur, Hispid Hare, Assam roofed turtle and so on. Located at the Himalayan foothills of India, MNP is shares land territory with Bhutan where it is known as the Royal Manas National Park. The park is composed majorly of grassland and a forest biome. It is covered by the Brahmaputra Valley semi-evergreen forest vegetation along with the Himalayan subtropical broadleaf forests and the Assam Valley semi-evergreen alluvial grassland vegetation. This renders MNP a region of rich and abundant biodiversity. Major trees include the Bombax ceibar, Gmelina arborea, Bauhini purpurea, Syzygium cumin, Aphanamixis polystachya, Oroxylum indcum, etc. The climate is sub-tropical with a warm and humid summer, followed by a cool and dry winter. Temperatures range from $10^{\circ} \mathrm{C}$ to $32^{\circ} \mathrm{C}$.

The park has more than 58 fringe villages directly or indirectly dependent upon it, distributed across three ranges: Bansibari, Bhuiyaparaa and Panbari. The village Agrang lies at MNP's core while most are located in its buffer zone. Spread over the State of Assam's Barpeta and Bongaigaon districts, the tribal population in its fringe areas predominantly include Bodos and Rabhas among which the practice of insect eating and rearing are widespread.

Insect sampling 
123 Insects were collected using entomological nets, beating tray, water traps, or through digging and

124 handpicking. The local people of the study area helped in the collection process. Insects were

125 usually collected during the early hours of the day (0500-0900 hours).

126 The flying insects were collected via entomological nets at a time when they were active (mid-

127 morning/late afternoon). Sweep nets were used for collecting grasshoppers and other insects

128 which hid in low grass- or herb-dominated vegetation and in small shrubs. Netting was normally

129 carried out during early hours of the day as we could not collect nocturnal taxa in this way. In

130 order to catch nocturnal species, we used light traps. Nocturnal arthropods like species of moths

131 and beetles are easily attracted towards artificial light sources. Light traps have therefore been

132 widely used in nocturnal insect sampling. A high-power CFL bulb was arranged in front of a

133 white cloth for trapping nocturnal insects. Generally, a bowl filled with water was placed under

134 the light sources in the evening, after rainfall, to attract termites. The light attracted the

135 reproductive termites which came out for nuptial flights and were trapped in the water or

136 collected by hand from the water to prevent them from escaping. Light trapping was used widely

137 in case of agricultural habitat type and open field habitat type.

138 Beating trays were used to collect insects such as Lepidoptera and Hymenoptera. Shrubs and

139 small trees were sampled through commonly used beating tray sample method. Moreover, the

140 red weaver ants were harvested by plucking the nest from the tree and dropping it in a bucket of

141 water before being sorted out for consumption. The soil dwelling edible insects were collected

142 by digging with the help of spades. Besides sweep netting, large insects such as grasshoppers and

143 beetles were also collected by hand which were caught early in the morning or in the evening

144 when they were less mobile due to their low body temperature. Mole and field crickets were dug

145 out of holes.

146 We used the hand-netting technique to collect the aquatic insects along with other local

147 traditional equipment like Jakoi, Chaloni, etc. The Jakoi is a species of wicker work shovel that

148 is either dragged along the bottom or placed on the water bed to catch the aquatic insects which

149 take refuge in it when the weed is trampled. It is prepared with bamboo slips, which are locally

150 known as 'dai'. 'Jati' bamboo is specially used for making this particular implement. Chaloni is

151 a bamboo strainer used to separate insects from collected water. Long handled aquatic net was

152 used to collect insects that live on the water surface. Many adult insects living on the surface

153 were predators, so they were removed from the net using forceps directly into a collection

154 container. The kick-net method which is a process where insects are collected by dislodging

155 them from the substrate (habitat) was also used. The organisms that were dislodged by the

156 disturbance were collected on the net.

157 For preservation of specimens, both dry and wet preservation methods were followed. For dry

158 preservation, the specimens were preserved using pins in insect cabinet box and were mainly

159 sun-dried. Soft-bodied insects were preserved using 70\% ethyl alcohol. Besides, some hard-

160 bodied edible insects were preserved using 2-3\% formaldehyde (Ghosh \& Sengupta, 1982).

161 Identification was done later by comparison with other specimens. Some were identified in the

162 Zoological Survey of India, Shillong, Meghalaya (India). 
163 Sampling was done from 20 chosen sites located around MNP during the period 2018 (June)-

164

165

166

167

168

169

170

171

172

173

174

175

176

177

178

179

180

181

182

183

184

185

186

187

188

189

190

191

192

193

194

195

196

197

198

199

200

201

202

2019 (June). The permission for conducting the field study was obtained from Office of the Principal Chief Conservator of Forests (Wildlife) and Chief Wildlife Warden, Government of Assam, India vide No. WL/FG31/ResearchStudyPermission/19th Meeting/2019. The remaining methodology of the study is outlined in Figure 2.

\section{Edible insect density, diversity and abundance}

Studying the diversity required us to divide each sampling point into four different habitat types, namely, open field habitat (OFH), forest/backyard forest habitat (FBH), swampy area habitat (SAH), and agricultural field habitat (AFH). The entire sampling area amounted to approximately $842 \mathrm{~km}^{2}$. Insects were recorded within quadrates (2m x $2 \mathrm{~m}$ dimension) established in the habitat type and monitored for four seasons, namely, pre-monsoon (March, April and May), monsoon (June. July, August and September), retreating monsoon (October and November), and winter (December, January and February) (Borthakur, 1986).

The Shannon-Wiener index (H') for diversity, Simpson index (D) for dominance, and Margalef index for species richness in the four selected habitat types were computed. Order-wise relative abundance and species-wise abundance in the different habitats were also computed. The descriptions and mathematical expressions are outlined below. The indices were estimated using PAST (v.3.26) (Hammer et al., 2019) and SPSS (v.23).

Shannon-Weiner index ( $\left.\mathrm{H}^{\prime}\right)$ determines the diversity of insect species in a particular habitat type. The higher the H' value, the greater is the diversity. Expression (i) gives the formula.

$\mathrm{H}^{\prime}=-\sum p_{\mathrm{i}} \ln p_{\mathrm{i}} \ldots \ldots$ (i)

Where $p_{i}=$ proportion of individuals found in $\mathrm{i}^{\text {th }}$ species

Simpson's index (D) defines the probability of drawing any two individuals at random from a very large community of the same species. If $\mathrm{D}$ increases, we can say that diversity has decreased. This index, defined by expression (ii), accounts for both aspects of diversity, i.e., richness and evenness.

$\mathrm{D}=\sum\left(\frac{\sum n_{i}\left[n_{i}-1\right]}{N[N-1]}\right) \ldots \ldots$

Where, $n_{i}=$ individuals in $i^{\text {th }}$ species, $\mathrm{N}=$ total number of individuals

Margalef's index (R) gives a precise idea about a species' richness. It attempts to compensate for the effects of sampling by taking a ratio of species richness by the total number of individuals in a sample, given in expression (iii).

$\mathrm{R}=(\mathrm{S}-1) / \ln \mathrm{N}$

Where, $\mathrm{S}=$ total species in a community, $\mathrm{N}=$ total number of individuals in that community.

\section{Entomophagy study}

Understanding the entomophagy attitudes and distribution among the tribal population near MNP required conducting a survey. Methods included interactions with the villagers through questionnaires, field surveys, and a market survey. The villages were selected randomly and were surveyed once per season for the whole year. Questions were asked to a mixed group of 
203 ethnic people which included individuals from all sections of the society. The market survey

204 helped record the economic importance of these insects for the local economy. Questions

205 pertained to the number of insects sold per week/month, their market prices, and how popular

206 were the insects in ethnic cuisine. Overall, the questionnaire survey included 2672 respondents

207 from 30 villages of which 981 were from the Adivashi tribe, 695 were Bodos, 436 were Saranias, 208422 were Rabhas and 138 were non-tribal individuals. Written consent was obtained from the 209 respondents during the field interviews.

210

211

\section{Results}

213 Table 1 shows the order-wise number of edible insects found in the study area. In MNP, the 214 order Orthopteran recorded the maximum number with 8 species, followed by Hymenoptera with 2154 species. The order Hemiptera was found to have 3 species followed by Lepidoptera and 216 Blattodea with 2 species each. The order Coleoptera, Mantodea, and Odonata accounted for 1 217 from each species and family. A total of 9,213 edible insects were recorded from AFH, 1455 in 218 FBH, 3435 in OFH and 6497 individuals in SAH, during the field observation. No common 219 abundant species was found in a single habitat. Most of the insects were found in two or three 220 habitats during the study period.

221

222

223

224

225

226

227

228

229

230

231

232

233

234

235

236

237

238

239

240

241

242

Table 2 showcases the types of edible insects consumed by the ethnic people. In this table, the local and common name (in Bodo), the scientific name with their taxonomy, and their seasonal availability, edible parts, and mode of consumption are tabulated. Common names in Bodo have been displayed in Table 2 as they were more popular among the local people. Seasonal availability was maximum during June to September, gradually reducing towards the winter season. Species of the order Orthoptera were most abundant in May to September, whereas, Coleopterans were usually available from April to September. Insects belonging to the Hemiptera and Hymenoptera were found to be restricted to the period lasting from April to October, whereas, Mantodea were available from June to October. Some edible insects like Lethocerus indicus, Periplaneta americana and Gryllotalpa africana were found to be available throughout the year, but in the winter, they were less abundant than during the pre-monsoon and monsoon season.

Simpson index (D) for dominance, Shannon-Wiener index (H') for diversity, and Margalef index for evenness/equitability were calculated in the four selected habitats (Table 3). Further, species abundance was found to be the highest in Chondracris rosea with 18.64, followed by Gryllotalpa africana with 8.50 in AFH. In FBH, the highest species abundance was found in Hieroglyphus banian with 8.91, followed by Polistis olivaceus with 5.20. In OFH, Gryllus bimaculatus was the highest abundant species with 5.1, followed by Lethocerus indicus with 3.17. Table 4 shows the relative abundance of the edible species in selected habitats. Chondracris rosea has the highest relative abundance (11.50\%) followed by Choroedocus

Peer) reviewing PDF | (2020:05:49115:3:2:NEW 3 Oct 2020) 
243 robustus (8.92\%), the least relative abundant insect species includes Laccotrephes ruber $244(0.42 \%)$.

245

246 Seasonal variation in abundance of edible insects (Figure 3) shows Periplaneta americana to be 247 the most abundant species with 798 individuals found in monsoon season followed by Mantis 248 religiosa with 466 individuals, and the least abundant species is Mecopoda elongata with 13 249 individuals. In pre-monsoon, Antheraea assama with 443 individuals has the highest presence 250 and Acheta domesticus with 3 individuals has the lowest. Choroedocus robustus has availability

251

252

253

254

255

256

257

258

259

260

261

262

263

264

265

266

267

268

269

270

\section{Discussion}

272 Edible insect diversity and abundance

273

274

275

276

277

278

279

280

281 consumption have been presented in Figure 7 . of 420 individuals during retreating monsoon compared to 10 individuals of Gryllus bimuculatus. Finally. In winter, Vespa affinis has the highest availability with 125 individuals, followed by Periplaneta americana with 112 individuals. The least number of individuals (12) was observed in case of Hieroglyphus banian. In general, highest number of insect species was observed during monsoon season with a total of 4808 individuals followed by pre-monsoon with 2758 individuals, retreating monsoon with 2106 individuals, and winter with 774 individuals.

Further, the proportion of ethnic communities practicing entomophagy in MNP has been graphically represented in Figure 4. As mentioned before, the 2672 respondents to our survey included 981 individuals from the Adivashi tribe, 695 from the Bodo tribe, 436 from the Sarania tribe, 422 from the Rabha tribe and a total of 138 individuals were non-tribal. We also categorised the respondents of our survey who considered the insect-eating habit favourable, into four age-groups, namely, less than 60 years, between 40-60 years, between 20-40 years and greater than 20 years (Figure 5). Consumers in the 20-40 group responded highly favourably while those in less than 20 years group responded less favourably owing to different variations of entomophobia. There are various reasons for eating insects which were found among the different ethnic groups during the questionnaire survey (Figure 6). The different modes of insect

As part of this study, we find that species of the order Orthoptera are popular among the ethnic people for consumption purposes. The edible species majorly include both short and long-horned grasshoppers (Eupreponotus inflatus, Choroedocus robustus, Chondracris rosea, Mecopoda elongata and Hieroglyphus banian), field crickets (Gryllus bimculatus), house crickets (Acheta domesticus) and mole crickets (Gryllotalpa Africana). Other species include potter wasp (Vespa affinis) and paper wasp (Polistis olivaceus), Indian honey bee (Apis indica) and rock bee (Apis dorsata), giant water bug (Lethocerus indicus) and some others. The ethnic (tribal) communities consuming these insects were mainly those of the Adivashis, followed by the Bodo, Rabha, and Sarania. A section of the non-tribal population also consumed insects as part of their diets. 
282 Species diversity, richness, and evenness gives an idea about the variety and diversity of species 283 in the study sites. The most commonly used dominance and diversity indices in ecology are the 284 Simpson index and the Shannon-Wiener index. Simpson index is used to assess the dominance 285 but fails to provide an idea about species richness. Shannon-Wiener index is expected to 286 determine both diversity characteristics (evenness and richness) but does not provide any 287 information on rare species which, however, are very important in studies of biodiversity. Our 288 results show that the species dominance is highest in FBH (0.3871), followed by SAH (0.2423), 289 OFH (0.1467), and AFH (0.1148). On the other hand, species diversity, as per H', was highest in 290 AFH (2.822), OFH (2.392), FBH (2.153) and SAH (1.329). This establishes the fact that as 291 insect diversity decreases, their dominance should increase. In MNP, this can be noticed for the forest habitat. Further, this result is corroborated by the Margalef index which is found to be highest for AFH (2.936), OFH (2.294), FBH (1.836), and SAH (0.653).

Notably, forest habitats are the prime source of edible insects for local people. This adverse finding in the case of FBH may be attributed to various reasons. Decreasing forest cover, changes in vegetation type, adverse climatic conditions, or indiscriminate collection and consumption of edible insect. These directly affect the insect diversity and rejuvenation of insect species. In the case of MNP, high temperatures, inadequate rainfall, and vegetation cover may also have influenced the population density of these edible insects. Notably, the overall climate of Assam has warmed by over $0.5^{\circ} \mathrm{C}$ for the past decade which is expected to rise up to $2.2^{\circ} \mathrm{C}$ by 2050.

It should be noted that Shannon-Weiner and Simpson diversities increase as richness increases for a given pattern of evenness, and increase as evenness increases for a given richness, but they do not always follow the same trend. Simpson diversity is less susceptible to richness and sensitive to evenness than Shannon index which, in turn, is more receptive to evenness. At the other extreme, the Berger-Parker index, depends entirely on evenness- it is simply the inverse of the proportion of individuals in the community that belongs to the single most common species, while the other indices (Margalef) are dependent on the number of species. Apart from the diversity and distribution patterns for insect taxa, interactions between insect groupings and plant groups are another important topic requiring urgent research attention. This is because plants provide key habitat parameters for many insect species ranging from shelter to breeding sites. This has not been covered under this study and could be pointed out as its limitation.

Our analysis of seasonal diversity of edible insect species shows that the diversity of the edible insects was greater during monsoon and pre-monsoon season, moderate in the retreating monsoon season, and lowest in the winter season. As per the survey report, it was found that the abundance of insects found today is much lower than what it was earlier. The decreasing pattern is corroborated by Doley \& Kalita (2011), Narzary \& Sarmah (2015), Das et al. (2012), with slight changes. This establishes that seasonal availability of edible insects is declining with time. 
322 Further, anthropogenic disturbances and deforestation are seen rampant in the fringes of MNP.

323 Ground-level evidence glaringly shows that villagers are converting forest lands into agricultural

324 fields. This is an outcome of the burgeoning population of Assam where the human population

325 density is 398 persons per $\mathrm{km}^{2}$ which is way above the global density of 14.7 persons per $\mathrm{km}^{2}$.

326 Such anthropogenic pressure (Morris, 2010) is bound to destroy species composition, community

327 structure, and insect diversity. This calls for urgent ecosystem restoration to sustain the

328 distribution pattern and abundance of edible insects.

329

330

331

332

333

334

335

336

337

338

339

340

341

342

343

344

345

346

347

348

349

350

351

352

353

354

355

356

357

358

359

360

361

In the regional context, a study of the diversity of insects consumed by the people in Dhemaji District of Assam revealed that a majority of 14 species of insects were used as food (Doley \& Kalita, 2011). 40 species of edible insects were recorded in Karbi Anglong District of Assam corroborated by Hanse \& Teron (2012). Another study involving the ethnic community of the Bodos, recorded 25 species of local insects, belonging to eight orders and fourteen families which are consumed as food (Narzary \& Sarmah, 2015).

\section{Entomophagy, food security, and its economic implications}

The field investigation revealed that most of the respondents found insects to be tasty and delicious (59\%), while a section found them to be an inexpensive source of food (17.1\%). Traditional medicinal food is also one of the reasons why edible insects are collected (MeyerRochow, 2017). This indicates the substantial preference of insects in the food habits of people and underscores their importance in the allocation of household costs and sustaining food security. This can be corroborated with the findings of Mozhui et al. (2017) for Nagaland, where the ethnic people considered insects as a regular food source, rather than an emergency food item. The local people favoured eating insects mostly by frying, roasting, or smoked. This emphasises the wide variety of ways through which insects may be consumed. However, a low percentage of respondents claimed them to be easily available food as collecting them is rather difficult compared to conventional livestock. This calls for the development of an insect farming industry as well. Further, a large number of respondents in the 20-40 years and 40-60 years age bracket favoured eating insects due to the various reasons as in Figure 5. Entomophagy, as such, is highly popular among the youth population. However, in Ethiopia young people are less inclined to eat or even taste insects (Ghosh et al. 2020).

Besides, the nutritional significance of edible insects has been well established by current scientific literature. It is observed that nutrients vary widely across insect species wherein some are rich in protein and lipids while others are rich in mineral content. Chen et al. (2009) note that edible insects are rich in protein and fat, but sometimes may lack carbohydrate content. However, insects like bees, honeypot ants, etc., are very rich in carbohydrates. Besides, Collavo et al. (2005) note that the presence of high essential amino acids is a major reason for insects having high-quality protein. Majority of the population near MNP belong to low- or lowermiddle-income category people. Their demography is skewed towards ethnic backgrounds and

Peer) reviewing PDF | (2020:05:49115:3:2:NEW 3 Oct 2020) 
362 hence, the economy is highly underdeveloped. Rearing livestock and maintaining animal 363 husbandry practices, require a substantial amount of money. The piggery sector is robust in this 364 area. Practicing this requires large amounts of land and also involves substantial capital.

365 However, the nutritional benefits gained from it are not enough to compensate for the effort.

366 Also, insects generally meet the WHO recommendation for amino acid content with nymphs

367 being their most abundant source. Coleoptera has a higher amount of protein than most livestock.

368 More importantly, edible insects bear many non-health related benefits related to environmental

369 and financial costs than livestock.

370

371 On the other hand, it is important to note that many edible insects require higher energy in 372 culture and contain higher sodium and saturated fat content (Payne et al., 2016). This diminishes

373 their worth as alternative nutrient sources to fight nutrition-related diseases. This is because the

374 saturated fat content of edible insects is not recommended for people with heart disease risk,

375 obesity, or metabolism issues. Further, some beetle or butterfly species produce dangerous toxins

376 that are harmful to human health. Such species must be identified before being consumed as food

377 (Blum, 1994). However, insects have very high micronutrient content which can be extracted or

378 consumed at a third of the cost than other food products.

379

380

381

382

383

384

385

386

387

388

389

390

391

392

393

394

395

396

397

398

399

400

401

MNP is a highly flood-ravaged area with untimely floods occurring during the sowing period. Floods in 2019 affected over a million people of Assam with a majority from the Baksa District (where MNP is located) and the adjacent district of Barpeta. This frequently uproots the livelihood of the local people rendering them vulnerable to high food insecurity. It should be noted that these ethnic people otherwise have decent livestock and animal husbandry resources. With floods, they tend to lose livestock in a large-scale manner. At this juncture, edible insects can play a significant role in maintaining the nutritional content of their diet intact.

Animal protein is superior to plant; therefore, the best protein supplements should include some animal protein. Thus, insects may provide for good quality protein ingredients to produce a high standard protein supplement for the food industry (Ssepuuya et al., 2017). It was also found that the lipid content of common insect larvae (37.87\%) are higher than the soybean $(14.60 \%)$. From the energy point of view, lipids are important because one gram of lipid provides more than 9 kcal of energy when oxidized in the body. Lipids are structural components of all tissues and indispensable in cell membranes structure and cell organelles (Drin, 2014). The fat content of pupae and larvae of edible Coleoptera is higher than that of the adult insect. These results coupled with the significant role played by edible insects in the local food habits make it undeniable that the desirability of food security in their context is valid as they can be considered as viable sources of macro- and micro-nutrients for human beings.

Edible insects such as beetles have been a rich source of proteins and also other nutrients for a long time and have been preferred over traditional livestock by several communities all over the 
402 world (Losey et al., 2006). For instance, indigenous communities of Mexico are involved in 403 buying and selling edible insects, which are also processed and sold in urban markets. Insects 404 have low-fat content and as such, there has been a high worldwide demand for edible insects. 405 Additionally, aquatic insects are commonly exported from South Asian nations to the United 406 States which are prepared and served in high-end eateries. The estimated size of this market was 407 approximately USD 40 million in 2015. Moreover, in the Lao PDR, insects can be found in 408 markets as ready-to-eat snacks or fried with lime leaves (Meyer-Rochow et al., 2008).

409 Concerning agriculture, beetles have been found to contribute more than a billion dollars in 410 environmental and economic benefits globally. This comes from the fact that they recycle cattle 411 manure, thereby, improving pasture growth, yielding high agricultural benefits, and thus, 412 augmenting the livelihood of agriculturalists. In the context of MNP, a gap in the literature has 413 been observed wherein comprehensive studies on beetles' economic benefits haven't been 414 witnessed.

415

416 Rearing insects can result in environmental benefits with respect to food and feed. Insects can 417 impact organic farming while helping to reduce environmental contamination, as they emit fewer 418 greenhouse gases and ammonia, compared with conventional livestock (Dangles \& Casas, 2019). 419 Given the inclination of Bodos and other tribes in eating insects and rearing them to an extent, 420 economic policies must target rearing practices of insects, rather than solely focussing on animal 421 husbandry. Therefore, several strategies could be employed that can help in efficiently and 422 sustainably making use of such natural biodiversity in augmenting the societal income and its 423 food security, following learnings of other countries like South Korea (Meyer-Rochow et al., 424 2019).

425

426 Our study confirms that edible insects are of considerable nutritional value and expanding their 427 acceptability as human food can be expected to improve the nutritional status of people and 428 possibly reduce the insects' costs. With a wider insect diversity, the nutritional status of people 429 should improve while costs get reduced (Dickie et al., 2019). For instance, mealworms consist of 430 six fatty acids and unsaturated omega-3 components that are equivalent to those found in 431 commonly consumed fishes, and also higher than those found in pigs and cattle (Raheem et al., 432 2019). Since nutrition has been one of the core components in the evolution of economic policies 433 as well as family welfare, it is necessary that the insect eating habits of ethnic people in the study 434 435 436 Certain insects like silkworms, honey bees, and as of late bumble bees and wasps have been 437 traditionally domesticated since they are of high economic value. As such, insect farming is 438 much needed in the study area. This concept is widely prevalent in Korea, Thailand, Vietnam, 439 and Laos PDR. Vertical farming is another technique that can strengthen local economics and 440 help exploiting new protein sources (Specht et al., 2019). Family-run enterprises are mostly 
441 involved in this business along with other firms that have commercialised insects as not only

442 food but also sources of protein and other health supplements.

443

444

445

446

447

448

449

450

451

452

453

454

455

456

457

458

459

460

461

462

463

464

465

466

467

468

469

470

471

472

473

474

475

476

477

478

479

480

Insect diversity can be critical for livelihood development since, in some developing countries, the poorest members of a society are engaged in gathering and rearing of mini-livestock (Mason et al., 2018). Industrial-scale interventions can also augment their livelihoods that have now been observed in the case of silkworms of Assam. Given the relatively process of rearing, accessibility, and transportation of insects, the people of the study area can immensely benefit if steps to set up an Insect Marketing Hub, assisted by an Insect Development Authority is set up. The hub should be created following a hub-and-spoke model that would not only pertain to processing and distribution matters but also training and $\mathrm{R} \& \mathrm{D}$ issues.

\section{Conclusions}

In this study, we recorded edible insect diversity and abundance, characteristics, and attitudes of the ethnic communities involved in entomophagy that are residing in the fringes of the Manas National Park, a Natural World Heritage Site. A total of 22 species of edible insects belonging to fifteen families and eight orders were recorded from different habitat types. Out of these 22 species, we recorded a maximum number of 8 Orthopteran species followed by Hymenoptera (4), Hemiptera (3), Lepidoptera (2), Blattodea (2) and 1 species each from Coleoptera, Odonata, and Mantodea. Diversity indices such as Shannon-Wiener, Simpson dominance, and Margalef indices were computed. Results of the study show that edible insect diversity has significantly decreased in the forest habitat. For a region highly dominated by entomophagy, such decreasing diversity raises a red flag. The field investigation showed that edible insects are highly sought after by local people. We identified the entomophagy practicing population mainly belonging to the Adivashi, Bodo, Rabha, and Sarania communities. They consume insects via different modes of preparation, such as fried, smoked, raw, etc. Moreover, people preferring entomophagy mainly belong to the youth (20-40 year) population. Therefore, our results conclude that MNP is a place vibrant with a high diversity, and abundance of edible insects. Further, it was found that these insects are good sources of protein, lipid, essential amino acids, omega-3, and omega-6 content, besides calcium, magnesium, and carbohydrate content. This validates edible insects as a future alternative source for an adequately nutrient-rich diet, proving to be majorly desirable in the context of food security. Preservation of such diversity necessitates the adoption of efficient and unique conservation techniques along with appropriate policymaking which can go a long way in augmenting greater insect diversity and also the food security of people in South Asia.

\section{Acknowledgements}

We would like to thank Mr. A.M. Singh, PCCF, Government of Assam, and the Director of Manas National Park for their incredible assistance and support throughout the study. We also

Peer) reviewing PDF | (2020:05:49115:3:2:NEW 3 Oct 2020) 
481

482

483

484

485

486

487

488

489

490

491

492

493

494

495

496

497

498

499

500

501

502

503

504

505

506

507

508

509

510

511

512

513

514

515

516

517

518

519

thank the Director, IAAST, Guwahati for his encouragement throughout the study. Special thanks to Prof. Scott V. Edwards, Curator of Ornithology in the Museum of Comparative Zoology, Harvard University for his valuable guidance. We express our sincere gratitude to the Swagat Health and Educational Trust for supporting this study through its entirety. We also thank the respondents and forest rangers/personnel associated with Manas National Park, for helping us in specimen collection and providing relevant valuable inputs. Lastly, heartfelt thanks go out to the Centre for Environment, Education and Economic Development (CEEED) for giving us excellent logistic support.

\section{References}

1. Bernard, T., \& Womeni, H. M. (2017). Entomophagy: Insects as food. Insect Physiology and Ecology, 233-249.

2. Borthakur, M. (1986). Weather and climate of north east India. Northeastern Geographer, 18 (1\&2), 20-27.

3. Blum, M. S. (1994). The limits of entomophagy: a discretionary gourmand in a world of toxic insects. The Food Insects Newsletter, 7(1), 1-6.

4. Bukkens, S.G. (1997). The nutritional value of edible insects. Ecology of Food and Nutrition, 36(2-4), 287-319.

5. Chakravorty, J., Ghosh, S., \& Meyer-Rochow, V. B. (2011). Practices of entomophagy and entomotherapy by members of the Nyishi and Galo tribes, two ethnic groups of the state of Arunachal Pradesh (North-East India). Journal of Ethnobiology and Ethnomedicine, 7(1), 5Chakravorty, J., Ghosh, S., \& Meyer-Rochow, V. B. (2013). Comparative survey of entomophagy and entomotherapeutic practices in six tribes of Eastern Arunachal Pradesh (India). Journal of Ethnobiology and Ethnomedicine, 9(1), 50.

6. Chen, X., Feng, Y., \& Chen, Z. (2009). Common edible insects and their utilization in China. Entomological research, 39(5), 299-303.

7. Collavo, A., Glew, R. H., Huang, Y. S., Chuang, L. T., Bosse, R. \& Paoletti, M. G. (2005). House cricket small-scale farming. Ecological implications of mini-livestock. Potential of insects, rodents, frogs and snails, 27, 515-540.

8. Dangles, O. \& Casas, J. (2019). Ecosystem services provided by insects for achieving sustainable development goals. Ecosystem Services, 35, 109-115.

9. Das, J. K., Hazarika, A. K., \& Khan, I. I. (2012). Nutritional value of some edible insects in Baksa District, BTAD, Assam. The Clarion-International Multidisciplinary Journal, 1(1), 112-115.

10. Dickie, F., Miyamoto, M. \& Collins, C. (2019). The Potential of Insect Farming to Increase Food Security. Intech Open Publications, United States. 
520

521

522

523

524

525

526

527

528

529

530

531

532

533

534

535

536

537

538

539

540

541

542

543

544

545

546

547

548

549

550

551

552

553

554

555

556

557

558

559

11. Doley, A.K. \& Kalita, J. (2011). An investigation on edible insects and their role in Socioeconomic development of rural communities, A case study on Edible insects of Dhemaji District of Assam (India). Social Science Researcher, 1, 1-11.

12. Drin, G. (2014). Topological regulation of lipid balance in cells. Annual Review of Biochemistry, 83, 51-77.

13. Dumont, H. J. (1987). A population study of Scapholeberis rammneri Dumont and Pensaert (Cladocera: Daphniidae). Hydrobiologia, 145(1), 275-284.

14. Elemo, B.O., Elemo, G.N., Makinde, M.A. \& Erukainure, O.L. (2011). Chemical evaluation of African palm weevil, Rhychophorus phoenicis, larvae as a food source. Journal of Insect Science, 11(1), 146-152.

15. Evans, J., Alemu, M. H., Flore, R., Frøst, M. B., Halloran, A., Jensen, A. B., ... \& Payne, C. (2015). 'Entomophagy': an evolving terminology in need of review. Journal of Insects as Food and Feed, 1(4), 293-305.

16. Ghosh, A. K., \& Sengupta, T. (1982). Handbook on insect collection, preservation and study. Zoological Survey of India, Kolkata.

17. Ghosh, S., Jung, C., Meyer-Rochow, V. B., \& Dekebo, A. (2020). Perception of entomophagy by residents of Korea and Ethiopia revealed through structured questionnaire. Journal of Insects as Food and Feed, 6(1), 59-64.

18. Hammer, Ø., Harper, D.A.T. and Ryan, P.D. (2019). Paleontological Statistics (PAST), ver. 3.26.

19. Hanse, R., \& Teron, R. (2012). Ethnozoological practices among the Karbi tribes in Karbi Anglong district of Assam (India). The Ecoscan, 1, 117-20.

20. Jongema, Y. (2015). List of edible insects of the world. Wageningen UR, Wageningen, the Netherlands.

21. Johnson, D. V. (2010). The contribution of edible forest insects to human nutrition and to forest management. In P.B. Durst, D.V. Johnson, R.N. Leslie and K. Shono (Eds.). Forest insects as food: Humans bite back (pp. 5-12). FAP Publications, Bangkok.

22. Khoury, C. K., Bjorkman, A. D., Dempewolf, H., Ramirez-Villegas, J., Guarino, L., Jarvis, A., ... \& Struik, P. C. (2014). Increasing homogeneity in global food supplies and the implications for food security. Proceedings of the National Academy of Sciences, 111(11), 4001-4006.

23. Losey, J.E. \& Vaughan, M. (2006). The Economic Value of Ecological Services Provided by Insects. BioScience, 56(4), 311-323.

24. Macadam, C. R., \& Stockan, J. A. (2017). The diversity of aquatic insects used as human food. Journal of Insects as Food and Feed, 3(3), 203-209.

25. Mason, J., Black, R., Booth, S., Brentano, A., Broadbent, B., Conolly, P., Finley, J., Goldin, J., Griffin, T., Hagen, K., Lesnik, J., Lewis, G., Pan, Z., Ramos, J.M., Ranalli, M., Rojas, G., Shockley, M., Stull, V.J., \& Swietlik, D. (2018). Fostering Strategies to Expand the Consumption of Edible Insects, The Value of a Tripartite Coalition between Academia, Industry, and Government. Current Developments in Nutrition, 2(8).

Peer] reviewing PDF | (2020:05:49115:3:2:NEW 3 Oct 2020) 
560

561

562

563

564

565

566

567

568

569

570

571

572

573

574

575

576

577

578

579

580

581

582

583

584

585

586

587

588

589

590

591

592

593

594

595

596

597

26. Meyer-Rochow, V. B. (1975). Can insects help to ease the problem of world food shortage. Search, 6(7), 261-262.

27. Meyer-Rochow, V. B., Nonaka, K., \& Boulidam, S. (2008). More feared than revered: insects and their impact on human societies (with some specific data on the importance of entomophagy in a Laotian setting). Entomologie heute, 20, 3-25.

28. Meyer-Rochow, V. B. (2017). Therapeutic arthropods and other, largely terrestrial, folkmedicinally important invertebrates: a comparative survey and review. Journal of Ethnobiology and Ethnomedicine, 13(1), 9.

29. Meyer-Rochow, V. B., Ghosh, S., \& Jung, C. (2019). Farming of insects for food and feed in South Korea: tradition and innovation. Berliner und Munchener Tierarztliche Wochenschrift, 132(5-6), 236-244.

30. Morris, R. J. (2010). Anthropogenic impacts on tropical forest biodiversity: a network structure and ecosystem functioning perspective. Philosophical Transactions of the Royal Society B: Biological Sciences, 365(1558), 3709-3718.

31. Mozhui, L., Kakati, L. N., \& Changkija, S. (2017). A study on the use of insects as food in seven tribal communities in Nagaland, Northeast India. Journal of Human Ecology, 60(1), 42-53.

32. Musundire, R., Zvidzai, J. C., \& Chidewe, C. (2014). Bio-active compounds composition in edible stinkbugs consumed in South-Eastern districts of Zimbabwe. International Journal of Biology, 6(3), 36.

33. Narzary, S., \& Sarmah, J. (2015). A study on the prevalence of entomophagy among the Bodos of Assam. Journal of entomology and zoological studies, 3(2), 315-320.

34. Payne, C. L. R., Scarborough, P., Rayner, M., \& Nonaka, K. (2016). Are edible insects more or less 'healthy' than commonly consumed meats? A comparison using two nutrient profiling models developed to combat over-and undernutrition. European journal of clinical nutrition, 70(3), 285-291.

35. Raheem, D., Raposo, A., Oluwole, O. B., Nieuwland, M., Saraiva, A., \& Carrascosa, C. (2019). Entomophagy: Nutritional, ecological, safety and legislation aspects. Food Research International, 126, 108672.

36. Ramos-Elorduy, J., Carbajal Valdés, L. A., \& Pino Moreno, J. M. (2012). Socioeconomic and cultural aspects associated with handling grasshopper germplasm in traditional markets of Cuautla, Morelos, Mexico. Journal of Human Ecology, 40(1), 8594.

37. Rattanapan, R. (2000). Edible insect diversity and cytogenetic studies on short-tail crickets (Genus Rachytrupes) in northeastern Thailand. Unpublished M.Sc. Thesis. Khon Kaen University, Thailand.

38. Rumpold, B. A., \& Schluter, O. K. (2013). Nutritional composition and safety aspects of edible insects. Molecular Nutrition \& Food Research, 57(5), 802-823. 
598

599

600

601

602

603

604

605

606

607

608

609

610

39. Shantibala, T., Lokeshwari, R. K., \& Debaraj, H. (2014). Nutritional and antinutritional composition of the five species of aquatic edible insects consumed in Manipur, India. Journal of Insect Science, 14(1).

40. Specht, K., Zoll, F., Schümann, H., Bela, J., Kachel, J., \& Robischon, M. (2019). How Will We Eat and Produce in the Cities of the Future? From Edible Insects to Vertical Farming-A Study on the Perception and Acceptability of New Approaches. Sustainability, 11(16), 4315.

41. Ssepuuya, G., Namulawa, V., Mbabazi, D., Mugerwa, S., Fuuna, P., Nampijja, Z. and Nakimbugwe, D. (2017). Use of insects for fish and poultry compound feed in subSaharan Africa, A systematic review. Journal of Insects as Food and Feed, 3(4), 289302.

42. Zhang, C.X., Tang, X.D. \& Cheng, J.A. (2008). The utilization and industrialization of insect resources in China. Entomological Research, 38(S1), S38-S47. 


\section{Figure 1}

Study Area.

(a) Map of India (๔ Google)

(b) Map indicating location of Manas National Park ( $\odot$ Google)

(c) Map depicting sampling sites (๔ ESRI)

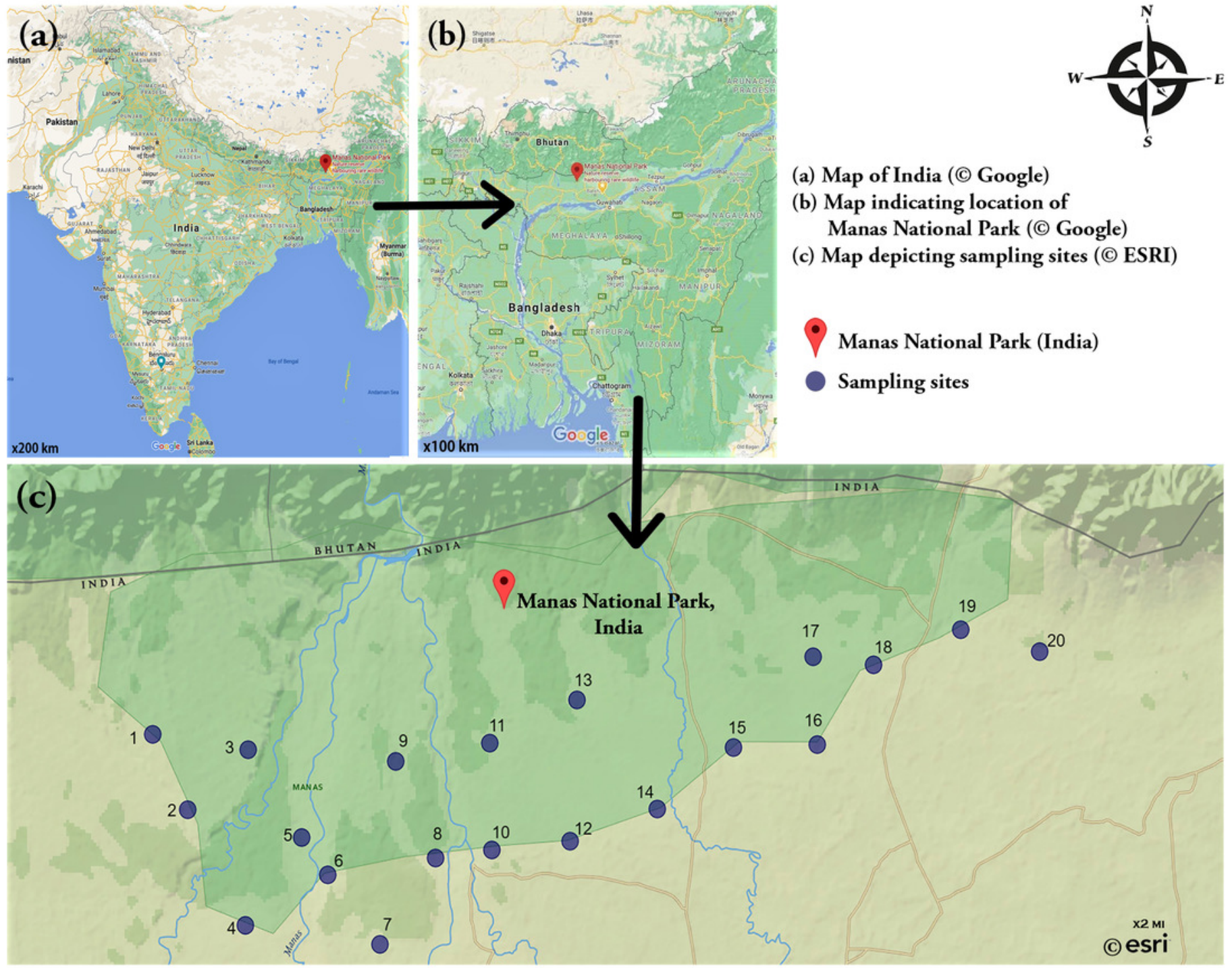


Figure 2

Methodology.

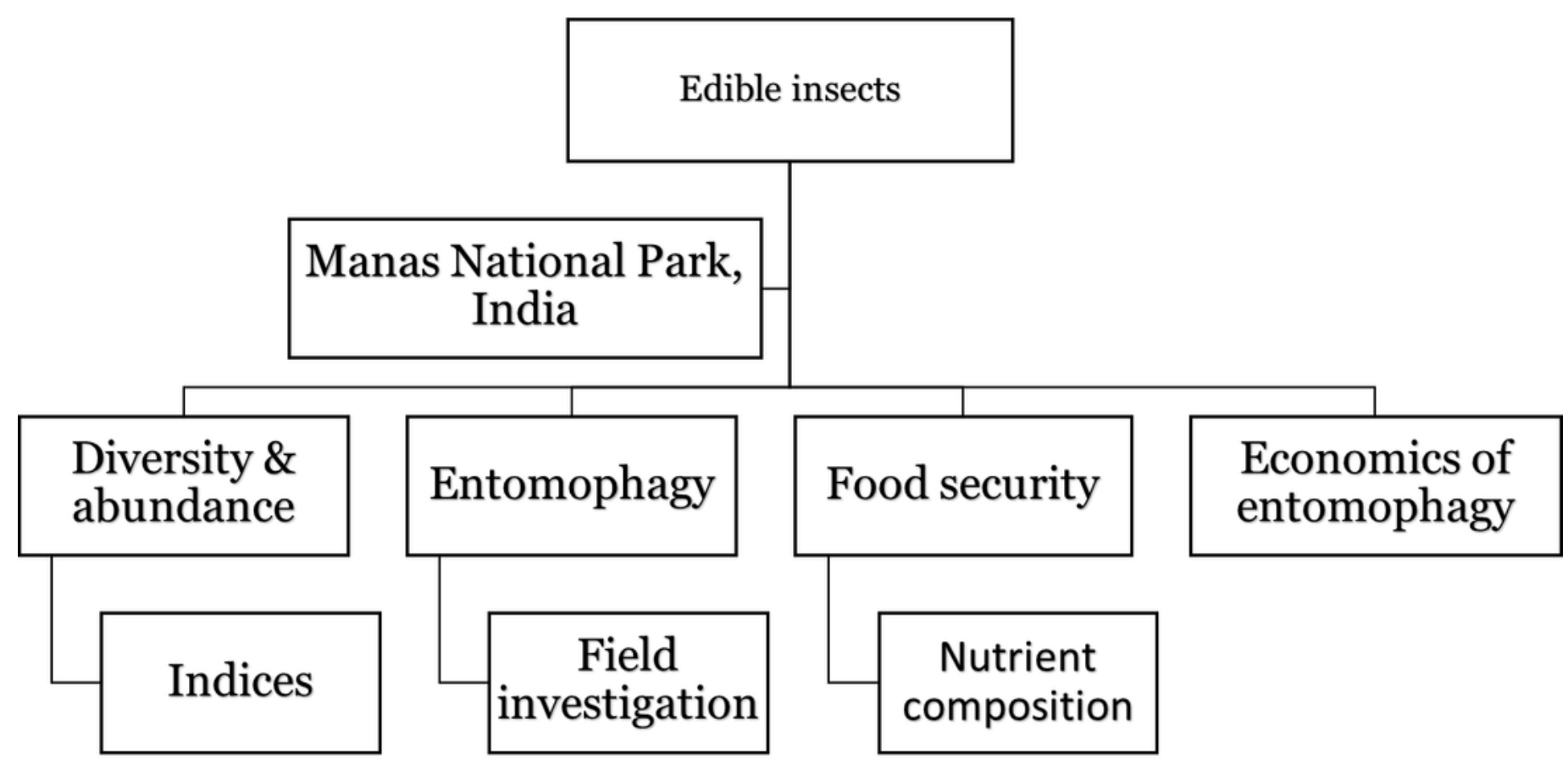




\section{Figure 3}

\section{Seasonal availability of insects.}

The legends in the figures are self-explanatory.

- Pre-monsoon a Monsoon $n$ Retreating Monsoon a Winter

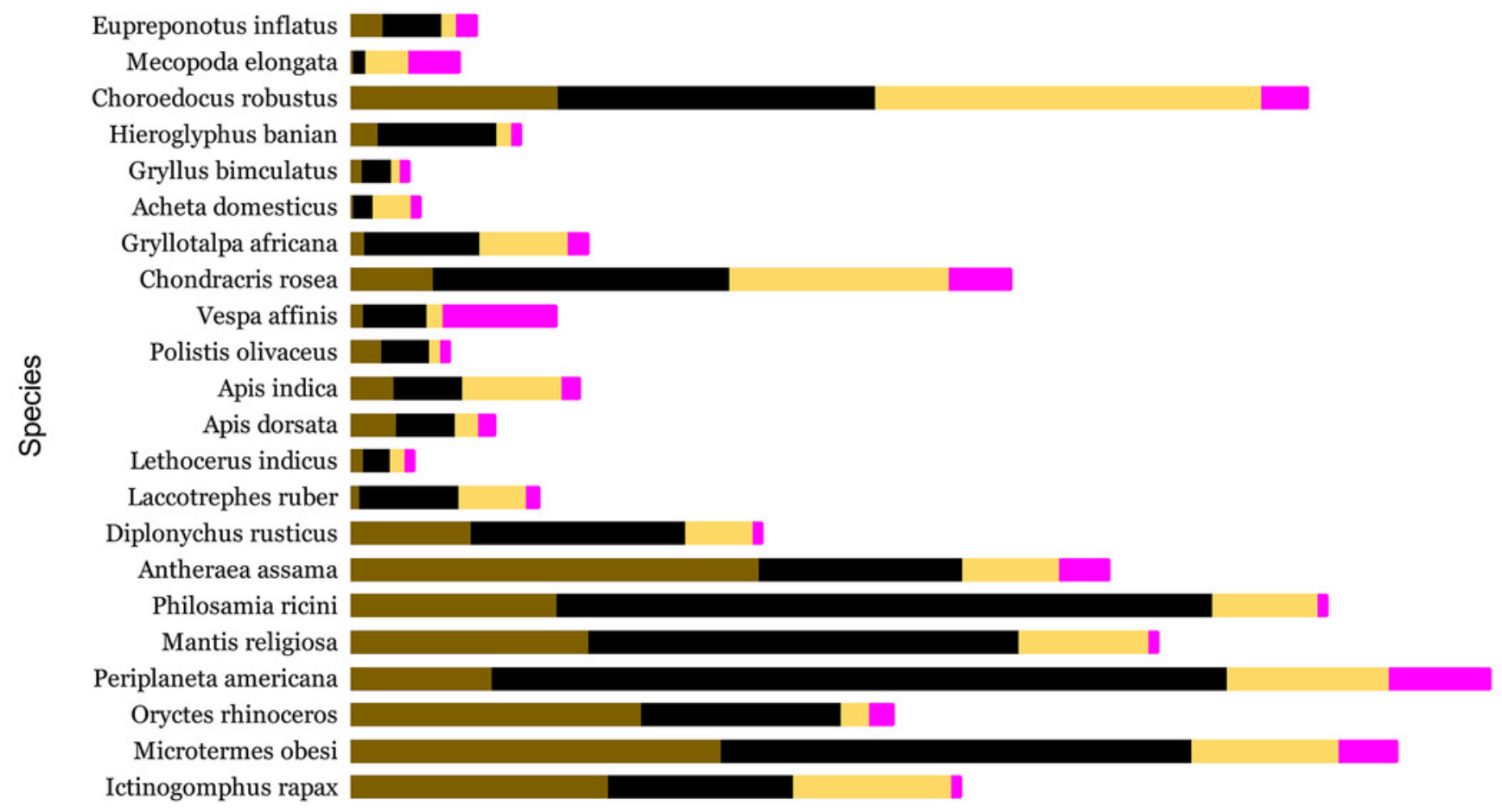




\section{Figure 4}

Entomophagy of different ethnic groups.

The black column indicates the respondent groups. The yellow column indicates the quantum of positive response. The numbers inside the columns indicates the number of people.

- Respondents 1 Positive response

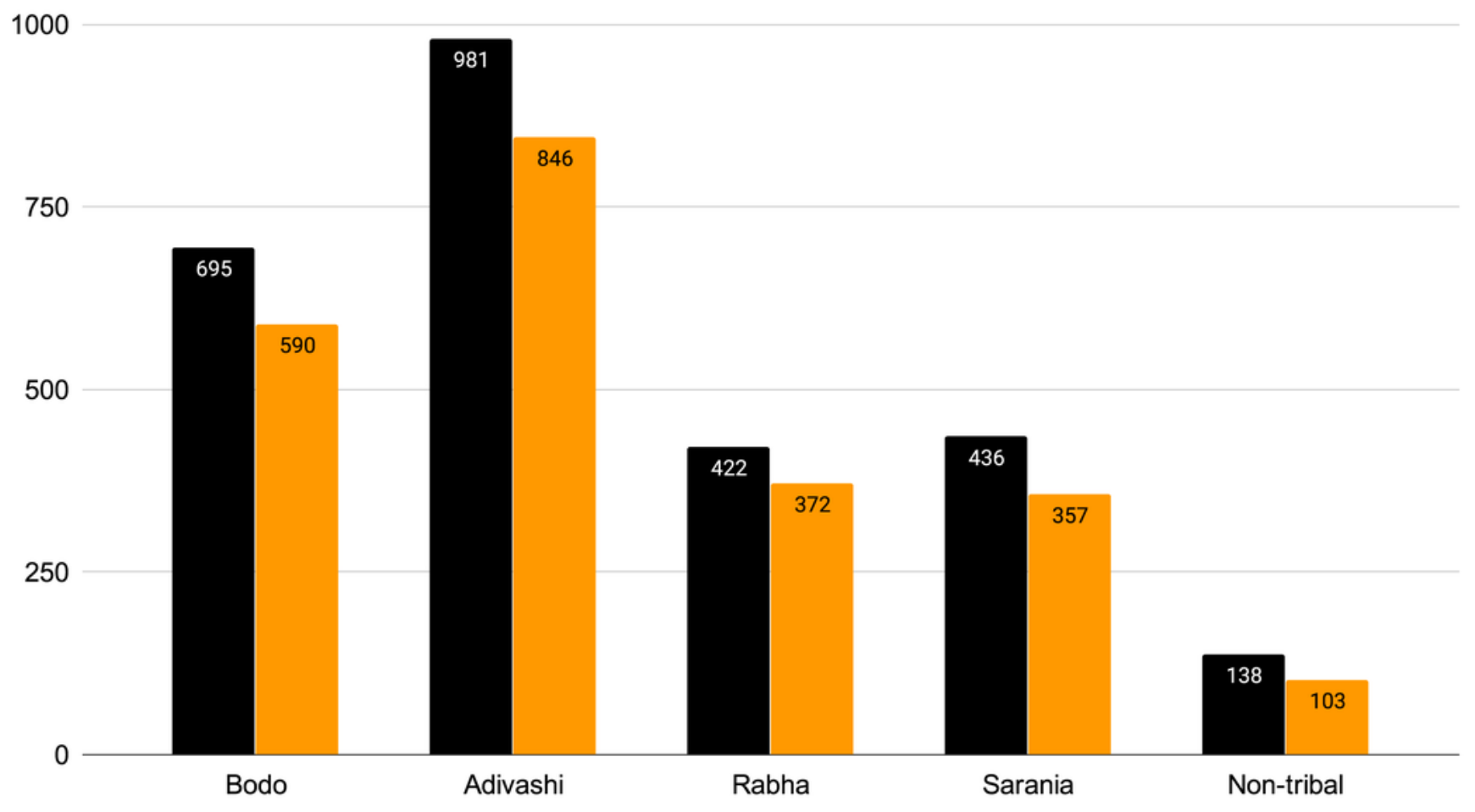




\section{Figure 5}

Age group of respondents favouring entomophagy.

The diagram is self-explanatory.

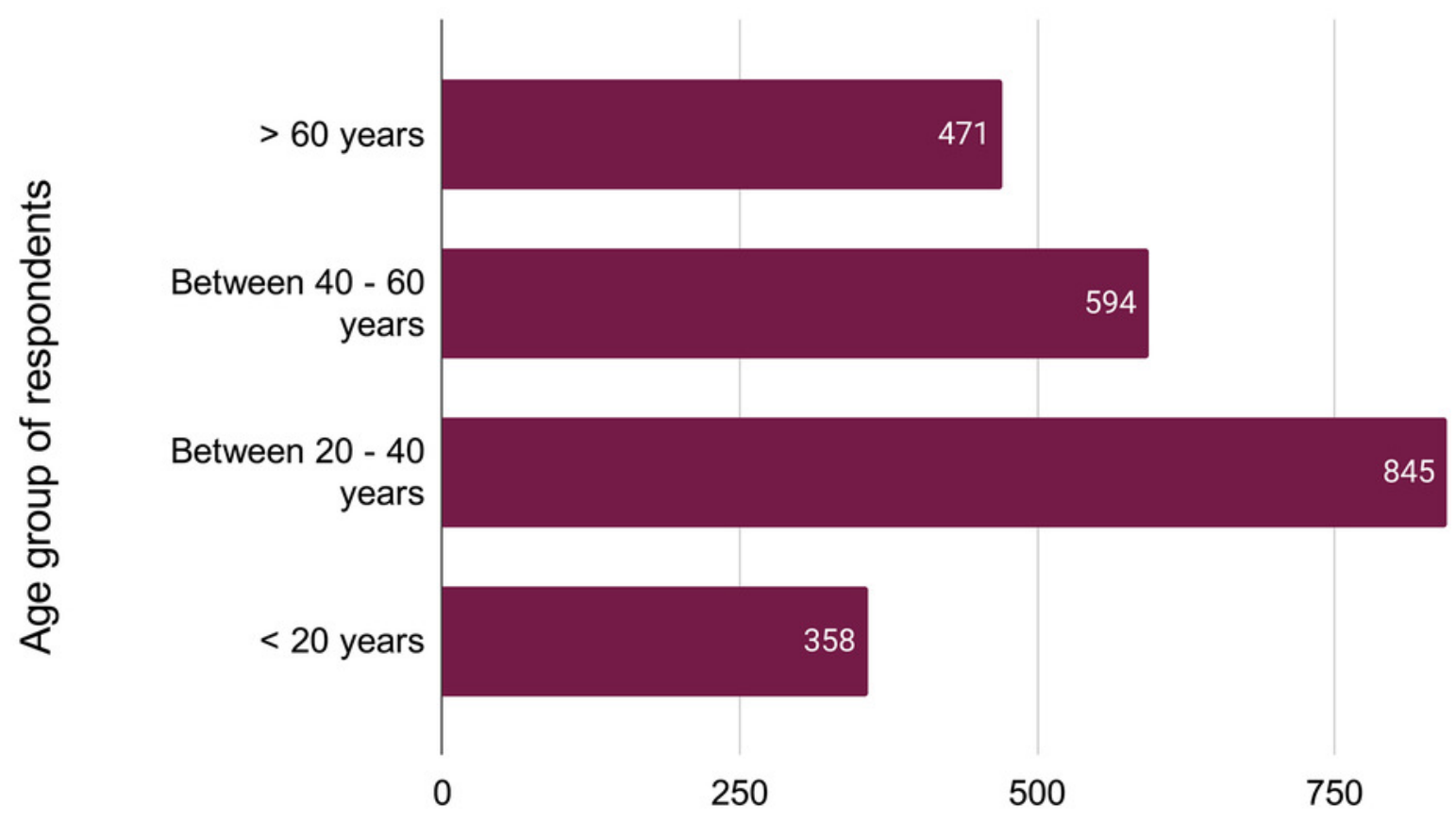

1000

Number of insect consumers 


\section{Figure 6}

Different reasons for practicing entomophagy.

The coloured sections of the pie display the different reasons why insect-eating (entomophagy) is practiced by the local people.

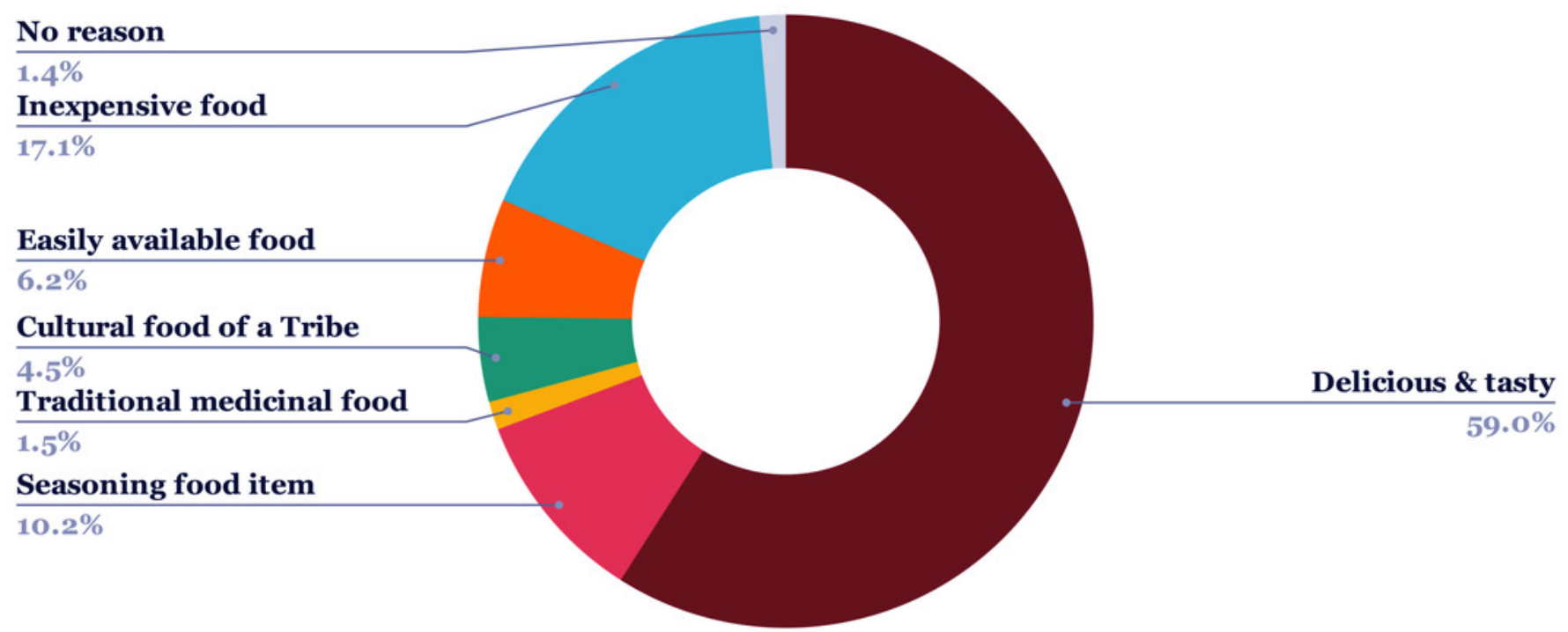




\section{Figure 7}

Different modes of eating insects.

The different coloured sections show the different modes/ways of eating insects by the local people.

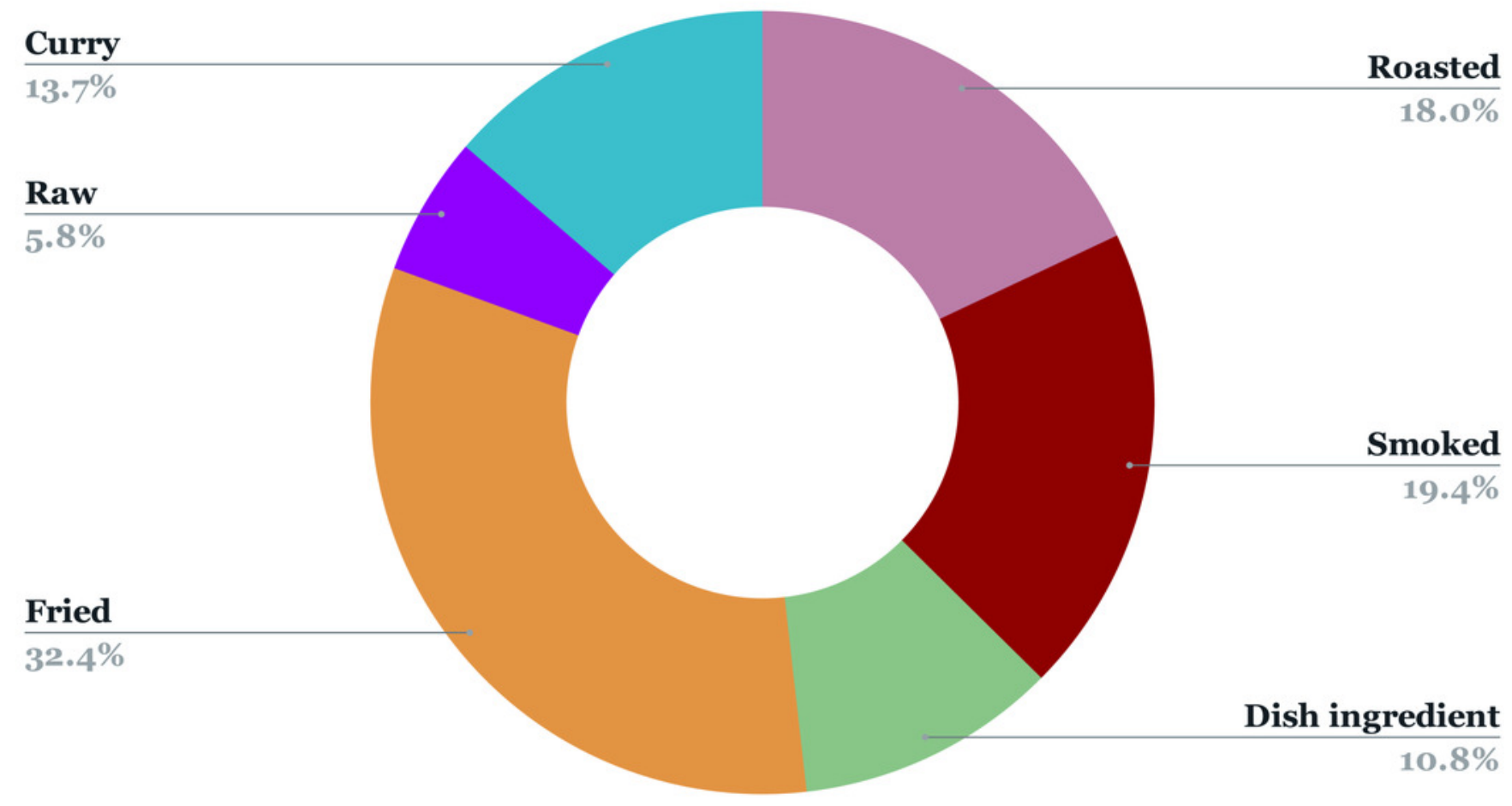




\section{Table $\mathbf{1}$ (on next page)}

Order-wise number of edible insects.

Each data point in the right column indicates the number of insects present in the speciestype specified in the left column. 
Table 1: Order-wise number of edible insects.

\begin{tabular}{|c|c|}
\hline Order & Number of species \\
\hline Orthoptera & 8 \\
\hline Hymenoptera & 4 \\
\hline Hemiptera & 3 \\
\hline Lepidoptera & 2 \\
\hline Blattodea & 2 \\
\hline Coleoptera & 1 \\
\hline Odonata & 1 \\
\hline Mantodea & 1 \\
\hline Total & 22 \\
\hline
\end{tabular}

2 


\section{Table 2 (on next page)}

Taxonomy with seasonal availability of edible insects in MNP.

Each data point indicates the scientific name, order, family, English name, local name, seasonal availability, edible part, and mode of eating of a particular edible insect. 
Table 2: Taxonomy with seasonal availability of edible insects in MNP.

\begin{tabular}{|c|c|c|c|c|c|c|c|}
\hline $\begin{array}{l}\text { Scientific } \\
\text { Name }\end{array}$ & Order & Family & $\begin{array}{c}\text { English } \\
\text { name }\end{array}$ & $\begin{array}{l}\text { Local } \\
\text { name } \\
\text { (Bodo) }\end{array}$ & $\begin{array}{l}\text { Seasonal } \\
\text { availabili } \\
\text { ty }\end{array}$ & $\begin{array}{c}\text { Edible } \\
\text { part }\end{array}$ & $\begin{array}{l}\text { Mode of } \\
\text { Eating }\end{array}$ \\
\hline $\begin{array}{c}\text { Eupreponot } \\
\text { us inflatus }\end{array}$ & Orthoptera & $\begin{array}{c}\text { Acridida } \\
\mathrm{e}\end{array}$ & $\begin{array}{c}\text { Short- } \\
\text { Horned } \\
\text { Grasshopp } \\
\text { er }\end{array}$ & $\begin{array}{c}\text { Gumanarg } \\
\mathrm{i}\end{array}$ & $\begin{array}{l}\text { May- } \\
\text { Sept }\end{array}$ & Adult & $\begin{array}{c}\text { Fried/smok } \\
\text { ed }\end{array}$ \\
\hline $\begin{array}{c}\text { Mecopoda } \\
\text { elongata }\end{array}$ & Orthoptera & $\begin{array}{l}\text { Tettigoni } \\
\text { idae }\end{array}$ & $\begin{array}{c}\text { Long } \\
\text { horned } \\
\text { grasshopp } \\
\text { er }\end{array}$ & $\begin{array}{c}\text { Gumakhuf } \\
\text { ri }\end{array}$ & $\begin{array}{l}\text { May- } \\
\text { Sept }\end{array}$ & Adult & $\begin{array}{c}\text { Roasted/fri } \\
\text { ed }\end{array}$ \\
\hline $\begin{array}{l}\text { Choroedoc } \\
\text { us robustus }\end{array}$ & Orthoptera & $\begin{array}{c}\text { Acridida } \\
\text { e }\end{array}$ & $\begin{array}{c}\text { Short- } \\
\text { Horned } \\
\text { Grasshopp } \\
\text { er }\end{array}$ & $\begin{array}{c}\text { Gumakhus } \\
\text { hep }\end{array}$ & June-Oct & Adult & Fried \\
\hline $\begin{array}{c}\text { Hieroglyph } \\
\text { us banian }\end{array}$ & Orthoptera & $\begin{array}{c}\text { Acridida } \\
\mathrm{e}\end{array}$ & $\begin{array}{c}\text { Grasshopp } \\
\text { er }\end{array}$ & $\begin{array}{c}\text { Gumagud } \\
\text { ul }\end{array}$ & June-Oct & Adult & $\begin{array}{c}\text { Fried/Smo } \\
\text { ked }\end{array}$ \\
\hline $\begin{array}{c}\text { Gryllus } \\
\text { bimaculatu } \\
s\end{array}$ & Orthoptera & $\begin{array}{c}\text { Gryllida } \\
\mathrm{e}\end{array}$ & $\begin{array}{c}\text { Field } \\
\text { Cricket }\end{array}$ & $\begin{array}{c}\text { Fendadan } \\
\text { gra }\end{array}$ & $\begin{array}{l}\text { May- } \\
\text { Sept }\end{array}$ & Adult & $\begin{array}{c}\text { Fried/Smo } \\
\text { ked }\end{array}$ \\
\hline $\begin{array}{c}\text { Acheta } \\
\text { domesticus }\end{array}$ & Orthoptera & $\begin{array}{c}\text { Gryllida } \\
\mathrm{e}\end{array}$ & $\begin{array}{l}\text { House } \\
\text { Cricket }\end{array}$ & Gusengra & $\begin{array}{c}\text { May- } \\
\text { Sept }\end{array}$ & Adult & $\begin{array}{c}\text { Fried/Smo } \\
\text { ked }\end{array}$ \\
\hline $\begin{array}{l}\text { Gryllotalpa } \\
\text { africana }\end{array}$ & Orthoptera & $\begin{array}{c}\text { Gryllotal } \\
\text { pidae }\end{array}$ & $\begin{array}{c}\text { Mole } \\
\text { cricket }\end{array}$ & Sosroma & $\begin{array}{l}\text { Whole } \\
\text { Year }\end{array}$ & Adult & $\begin{array}{c}\text { Fried/Smo } \\
\text { ked }\end{array}$ \\
\hline $\begin{array}{c}\text { Chondracri } \\
\text { s rosea }\end{array}$ & Orthoptera & $\begin{array}{c}\text { Acridida } \\
\mathrm{e}\end{array}$ & $\begin{array}{c}\text { Short } \\
\text { horned } \\
\text { Grasshopp } \\
\text { er }\end{array}$ & $\begin{array}{c}\text { Gumanare } \\
\text { nga }\end{array}$ & $\begin{array}{l}\text { June- } \\
\text { Aug }\end{array}$ & Adult & Fried \\
\hline $\begin{array}{l}\text { Vespa } \\
\text { affinis }\end{array}$ & $\begin{array}{l}\text { Hymenopt } \\
\text { era }\end{array}$ & $\begin{array}{c}\text { Vespida } \\
\mathrm{e}\end{array}$ & $\begin{array}{l}\text { Potter } \\
\text { wasp }\end{array}$ & $\begin{array}{c}\text { Handilore } \\
\text { bere }\end{array}$ & $\begin{array}{l}\text { Apr- } \\
\text { Sept }\end{array}$ & $\begin{array}{c}\text { Eggs } \\
\& \\
\text { Larvae }\end{array}$ & $\begin{array}{c}\text { Raw/Roast } \\
\text { ed/Fried, }\end{array}$ \\
\hline $\begin{array}{c}\text { Polistis } \\
\text { olivaceus }\end{array}$ & $\begin{array}{c}\text { Hymenopt } \\
\text { era }\end{array}$ & $\begin{array}{c}\text { Vespida } \\
\text { e }\end{array}$ & $\begin{array}{l}\text { Paper } \\
\text { wasp }\end{array}$ & Jothabere & Apr-Oct & $\begin{array}{c}\text { Eggs } \\
\& \text { Larv } \\
\text { ae }\end{array}$ & $\begin{array}{c}\text { Raw/Fried } \\
\text { Smoked }\end{array}$ \\
\hline Apis indica & $\begin{array}{c}\text { Hymenopt } \\
\text { era }\end{array}$ & Apidae & $\begin{array}{c}\text { Indian } \\
\text { honey bee }\end{array}$ & Maoubere & $\begin{array}{l}\text { May- } \\
\text { Sept }\end{array}$ & $\begin{array}{c}\text { Eggs } \\
\& \\
\text { larvae }\end{array}$ & Raw \\
\hline $\begin{array}{c}\text { Apis } \\
\text { dorsata }\end{array}$ & $\begin{array}{l}\text { Hymenopt } \\
\text { era }\end{array}$ & Apidae & Rock bee & Berema & $\begin{array}{l}\text { May- } \\
\text { Sept }\end{array}$ & $\begin{array}{c}\text { Eggs } \\
\& \\
\text { larvae }\end{array}$ & Raw \\
\hline $\begin{array}{l}\text { Lethocerus } \\
\text { indicus }\end{array}$ & Hemiptera & $\begin{array}{l}\text { Belosto } \\
\text { matidae }\end{array}$ & $\begin{array}{c}\text { Giant } \\
\text { Water bug }\end{array}$ & Gangjema & $\begin{array}{l}\text { Whole } \\
\text { Year }\end{array}$ & Adult & $\begin{array}{c}\text { Fried/Smo } \\
\text { ked }\end{array}$ \\
\hline $\begin{array}{l}\text { Laccotreph } \\
\text { es ruber }\end{array}$ & Hemiptera & Nepidae & $\begin{array}{c}\text { Water } \\
\text { scorpion }\end{array}$ & $\begin{array}{c}\text { Omabund } \\
\text { a }\end{array}$ & Jun-Oct & Adult & $\begin{array}{c}\text { Fried/Smo } \\
\text { ked }\end{array}$ \\
\hline $\begin{array}{l}\text { Diplonychu } \\
\text { s rusticus }\end{array}$ & Hemiptera & $\begin{array}{l}\text { Belosto } \\
\text { matidae }\end{array}$ & $\begin{array}{c}\text { Water } \\
\text { beetle }\end{array}$ & $\begin{array}{c}\text { Amphu } \\
\text { Dabla }\end{array}$ & $\begin{array}{c}\text { May- } \\
\text { Sept }\end{array}$ & Adult & $\begin{array}{c}\text { Fried/Curr } \\
\mathrm{y}\end{array}$ \\
\hline $\begin{array}{c}\text { Antheraea } \\
\text { assama }\end{array}$ & $\begin{array}{c}\text { Lepidopter } \\
\mathrm{a} \\
\end{array}$ & $\begin{array}{c}\text { Saturnid } \\
\text { ae }\end{array}$ & $\begin{array}{c}\text { Muga } \\
\text { silkworm }\end{array}$ & $\begin{array}{c}\text { Amphumu } \\
\text { ga }\end{array}$ & Apr-Sept & Larvae & Fried \\
\hline
\end{tabular}




\begin{tabular}{|c|c|c|c|c|c|c|c|}
\hline & & & & & & Pupae & \\
\hline $\begin{array}{l}\text { Philosamia } \\
\text { ricini }\end{array}$ & $\begin{array}{c}\text { Lepidopter } \\
\text { a }\end{array}$ & $\begin{array}{c}\text { Saturnid } \\
\text { ae }\end{array}$ & $\begin{array}{c}\text { Eri } \\
\text { silkworm }\end{array}$ & $\begin{array}{c}\text { Amphoula } \\
\text { ta }\end{array}$ & Apr-Sept & $\begin{array}{c}\text { Larvae } \\
\text {, } \\
\text { Pupae }\end{array}$ & Fried \\
\hline $\begin{array}{c}\text { Mantis } \\
\text { religiosa } \\
\end{array}$ & Mantodea & $\begin{array}{c}\text { Mantida } \\
\mathrm{e}\end{array}$ & $\begin{array}{c}\text { Praying } \\
\text { mantis }\end{array}$ & $\begin{array}{c}\text { Gumagan } \\
\mathrm{gu}\end{array}$ & $\begin{array}{l}\text { June- } \\
\text { Nov }\end{array}$ & Adult & $\begin{array}{c}\text { Fried/Smo } \\
\text { ked }\end{array}$ \\
\hline $\begin{array}{l}\text { Periplaneta } \\
\text { americana }\end{array}$ & Blattodea & $\begin{array}{c}\text { Blattelli } \\
\text { dae }\end{array}$ & $\begin{array}{c}\text { Cockroac } \\
\mathrm{h}\end{array}$ & $\begin{array}{c}\text { Thaoamph } \\
\text { ow }\end{array}$ & $\begin{array}{c}\text { Whole } \\
\text { year }\end{array}$ & Adult & Fried \\
\hline $\begin{array}{c}\text { Oryctes } \\
\text { rhinoceros }\end{array}$ & Coleoptera & $\begin{array}{c}\text { Scarabae } \\
\text { idae }\end{array}$ & $\begin{array}{l}\text { Rhinocero } \\
\text { s beetle }\end{array}$ & Jeljer & Sept-Feb & $\begin{array}{l}\text { Larvae } \\
\text { (Grubs } \\
\text { ) }\end{array}$ & Fried \\
\hline $\begin{array}{c}\text { Microterme } \\
\text { s obesi }\end{array}$ & Blattodea & $\begin{array}{c}\text { Termitid } \\
\text { ae }\end{array}$ & Termite & Wuri & Mar-July & $\begin{array}{l}\text { Larvae } \\
\text {, Adult }\end{array}$ & Fried \\
\hline $\begin{array}{l}\text { Ictinogomp } \\
\text { hus rapax }\end{array}$ & Odonota & $\begin{array}{c}\text { Gomphi } \\
\text { dae }\end{array}$ & $\begin{array}{c}\text { Dragon } \\
\text { fly }\end{array}$ & Gandula & Mar-Aug & $\begin{array}{c}\text { Nymp } \\
\mathrm{h}\end{array}$ & Fried \\
\hline
\end{tabular}

2

3

4

5

6

7 


\section{Table 3(on next page)}

Diversity indices (habitat type) of edible insects recovered from four selected habitats.

Each data points indicate the different diversity indices of a particular insect type with respect to different habitat types. 
1 Table 3: Diversity indices (habitat type) of edible insects recovered from four selected habitats.

\begin{tabular}{|c|c|c|c|c|}
\hline & AFH & FBH & SAH & OFH \\
\hline Species Richness & 24 & 22 & 6 & 23 \\
\hline $\begin{array}{c}\text { Total individuals } \\
\text { encountered }\end{array}$ & 9213 & 1455 & 3435 & 6497 \\
\hline Simpson & 0.1148 & 0.3871 & 0.2423 & 0.1467 \\
\hline Shannon-Wiener & 2.822 & 2.153 & 1.329 & 2.392 \\
\hline Margalef & 2.936 & 1.836 & 0.653 & 2.294 \\
\hline
\end{tabular}

AFH: Agricultural field habitat; FBH: Forest/backyard forest habitat; SAH: Swampy area habitat;

OFH: Open field habitat 


\section{Table 4(on next page)}

Abundance of edible insect in different terrestrial habitats.

Each data point shows the abundance of different edible insects in the terrestrial habitat types chosen in our study. 
Table 4: Abundance of edible insect in three different terrestrial habitats.

\begin{tabular}{|c|c|c|c|c|c|c|c|c|c|c|}
\hline Order & Species & $\mathrm{AFH}$ & $\begin{array}{l}\text { Quadrate } \\
\text { Occurrence }\end{array}$ & Abundance & FBH & $\begin{array}{l}\text { Quadrate } \\
\text { Occurrence }\end{array}$ & Abundance & $\mathrm{OFH}$ & $\begin{array}{l}\text { Quadrate } \\
\text { Occurrence }\end{array}$ & Abundance \\
\hline Orthoptera & $\begin{array}{c}\text { Eupreponotus } \\
\text { inflatus }\end{array}$ & 44 & 27 & 1.63 & 0 & 0 & 0.00 & 0 & 0 & 0.00 \\
\hline Orthoptera & $\begin{array}{c}\text { Mecopoda } \\
\text { elongata }\end{array}$ & 212 & 128 & 1.66 & 4 & 3 & 1.33 & 384 & 152 & 2.53 \\
\hline Orthoptera & $\begin{array}{c}\text { Choroedocus } \\
\text { robustus }\end{array}$ & 67 & 39 & 1.72 & 20 & 9 & 2.22 & 41 & 11 & 3.73 \\
\hline Orthoptera & $\begin{array}{l}\text { Hieroglyphus } \\
\text { banian }\end{array}$ & 31 & 21 & 1.48 & 78 & 13 & 6.00 & 72 & 24 & 3.00 \\
\hline Orthoptera & $\begin{array}{c}\text { Gryllus } \\
\text { bimaculatus }\end{array}$ & 12 & 9 & 1.33 & 44 & 11 & 4.00 & 5 & 4 & 1.25 \\
\hline Orthoptera & $\begin{array}{c}\text { Acheta } \\
\text { domesticus }\end{array}$ & 11 & 8 & 1.38 & 5 & 3 & 1.67 & 0 & 0 & 0.00 \\
\hline Orthoptera & $\begin{array}{l}\text { Gryllotalpa } \\
\text { africana }\end{array}$ & 24 & 17 & 1.41 & 3 & 2 & 1.50 & 4 & 2 & 2.00 \\
\hline Orthoptera & $\begin{array}{c}\text { Chondracris } \\
\text { rosea }\end{array}$ & 58 & 23 & 2.52 & 6 & 3 & 2.00 & 25 & 6 & 4.17 \\
\hline Hymenoptera & Vespa affinis & 0 & 0 & 0.00 & 110 & 76 & 1.45 & 28 & 8 & 3.50 \\
\hline Hymenoptera & Polistis olivaceus & 13 & 2 & 6.50 & 87 & 49 & 1.78 & 35 & 13 & 2.69 \\
\hline Hymenoptera & Apis indica & 43 & 36 & 1.19 & 189 & 49 & 3.86 & 44 & 42 & 1.05 \\
\hline Hymenoptera & Apis dorsata & 4 & 1 & 4.00 & 178 & 72 & 2.47 & 3 & 1 & 3.00 \\
\hline Hemiptera & Lethocerus & 2 & 1 & 2.00 & 7 & 7 & 1.00 & 88 & 46 & 1.91 \\
\hline
\end{tabular}




\begin{tabular}{|c|c|c|c|c|c|c|c|c|c|c|}
\hline & indicus & & & & & & & & & \\
\hline Hemiptera & $\begin{array}{c}\text { Laccotrephes } \\
\text { ruber }\end{array}$ & 112 & 45 & 2.49 & 28 & 21 & 1.33 & 74 & 60 & 1.23 \\
\hline Hemiptera & $\begin{array}{l}\text { Diplonychus } \\
\text { rusticus }\end{array}$ & 212 & 67 & 3.16 & 56 & 29 & 1.93 & 184 & 89 & 2.07 \\
\hline Lepidoptera & $\begin{array}{c}\text { Antheraea } \\
\text { assama }\end{array}$ & 251 & 71 & 3.54 & 155 & 59 & 2.63 & 445 & 148 & 3.01 \\
\hline Lepidoptera & Philosamia ricini & 988 & 56 & 17.64 & 24 & 11 & 2.18 & 76 & 44 & 1.73 \\
\hline Mantodea & Mantis religiosa & 1256 & 206 & 6.10 & 8 & 7 & 1.14 & 40 & 27 & 1.48 \\
\hline Blattodea & $\begin{array}{c}\text { Periplaneta } \\
\text { americana }\end{array}$ & 1205 & 212 & 5.68 & 0 & 0 & 0.00 & 73 & 32 & 2.28 \\
\hline Coleoptera & $\begin{array}{l}\text { Oryctes } \\
\text { rhinoceros }\end{array}$ & 56 & 48 & 1.17 & 29 & 16 & 1.81 & 532 & 153 & 3.48 \\
\hline Blattodea & $\begin{array}{c}\text { Microtermes } \\
\text { obesi }\end{array}$ & 41 & 8 & 5.13 & 79 & 45 & 1.76 & 1043 & 208 & 5.01 \\
\hline Odonota & $\begin{array}{l}\text { Ictinogomphus } \\
\text { rapax }\end{array}$ & 1224 & 212 & 5.77 & 0 & 0 & 0.00 & 66 & 21 & 3.14 \\
\hline
\end{tabular}

